\title{
Unusual pattern of neonatal hyperhidrosis
}

\author{
Erica Torres, ${ }^{1}$ Antoine Fauconneau ${ }^{2}$ Aurore Fougerouse, ${ }^{2}$ Franck Boralevi ${ }^{2}$
}

${ }^{1}$ Department of Paediatric Unit, Hospital de Faro, Centro Hospitalar do Algarve, Faro, Portugal

${ }^{2}$ Department of Paediatric Dermatology Unit, Children's University Hospital of Bordeaux, Bordeaux, France

\section{Correspondence to}

Dr Erica Torres, ericamtorres@gmail.com

Accepted 4 December 2015

\section{CrossMark}

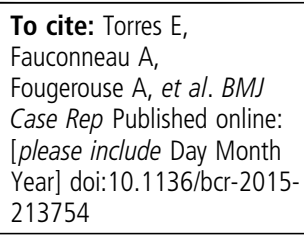

\section{DESCRIPTION}

A 10-day-old Caucasian boy presented at the emergency department with a history of excessive sweating in the last 3 days, especially during feedings (figure 1).

On presentation, the patient was systemically well without fever or irritability. A distinct unilateral transient flushing and hyperhidrosis of the trunk became apparent only when the baby was suddenly laid down for examination, and this was corroborated by the pattern of sweat marks on one side of his clothes. In contrast, the other half of his body remained pale and anhidrotic (figure 2). These signs were hitherto unknown by the parents. These findings were consistent with the diagnosis of Harlequin Phenomenon (HP). The baby's symptoms resolved spontaneously after 3 months.

In the newborn, HP consists of a sudden and brief midline change in skin colour. Its frequency in the neonatal period is uncertain, but it seems to be a rare phenomenon. It mainly occurs between the second and sixth day of life and more frequently affects preterm and small for gestational age infants. ${ }^{1}$ Besides being gravity dependent, other triggers remain unknown in HP. When lying in the lateral decubitus position, the dependent side becomes plethoric in contrast to the upper side, which becomes pale. Ipsilateral hyperhidrosis has been described in older children and adults, in

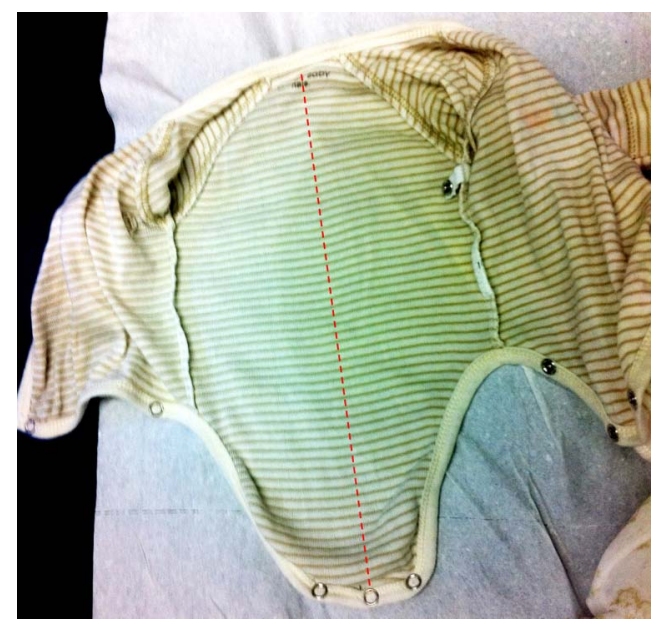

Figure 1 Unilateral hyperhidrosis, requiring multiple changes of clothes. The red line illustrates the body's midline.

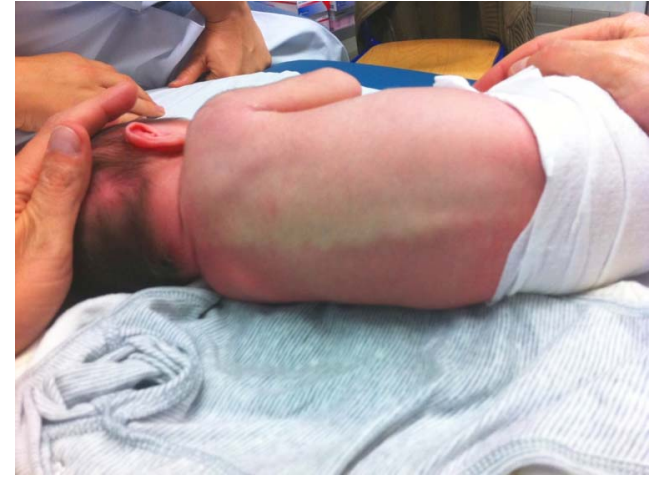

Figure 2 Unilateral flushing and hyperhidrosis of the trunk, appearing only when the baby was laid down.

familial cases or in association with Horner's syndrome, but not in healthy newborns. ${ }^{2}{ }^{3}$ The transient and benign evolution of this case supports the hypothesis of transient vasomotor instability resulting from hypothalamic immaturity as the main pathophysiological mechanism. ${ }^{1}$

\section{Learning points}

Ipsilateral hyperhidrosis associated with harlequin phenomenon in the healthy newborn has not been previously described.

- This case suggests that this association is benign and transient. No treatment is required.

Contributors ET collected the data and wrote the manuscript. AFa reviewed the manuscript. AFo collected the data and reviewed the manuscript. FB collected the data and reviewed the manuscript.

Competing interests None declared.

Patient consent Obtained.

Provenance and peer review Not commissioned; externally peer reviewed.

\section{REFERENCES}

1 Januário G, Salgado M. The Harlequin phenomenon. J Eur Acad Dermatol Venereol 2011;25:1381-4.

2 Yokoyama T, Toga A, Hashida Y, et al. Hemifacial flushing after bathing and crying. J Pediatr 2012;160:1058-9.

3 Choi JS, Boralevi F, Brissaud O, et al. Paroxysmal extreme pain disorder: a molecular lesion of peripheral neurons. Nat Rev Neurol 2011;7:51-5. 
Copyright 2015 BMJ Publishing Group. All rights reserved. For permission to reuse any of this content visit http://group.bmj.com/group/rights-licensing/permissions.

BMJ Case Report Fellows may re-use this article for personal use and teaching without any further permission.

Become a Fellow of BMJ Case Reports today and you can:

- Submit as many cases as you like

- Enjoy fast sympathetic peer review and rapid publication of accepted articles

- Access all the published articles

- Re-use any of the published material for personal use and teaching without further permission

For information on Institutional Fellowships contact consortiasales@bmjgroup.com

Visit casereports.bmj.com for more articles like this and to become a Fellow 